\title{
Does stopping left-right nodal flow mirror impaired mechanosensation in the left-right organizer?
}

\author{
R Jacinto ${ }^{*}$, P Sampaio, M Roxo-Rosa, SS Lopes \\ From Cilia 2014 - Second International Conference \\ Paris, France. 18-21 November 2014
}

\section{Background}

In most vertebrates organ asymmetries arise in early development through the left-right organizer (LRO). LRO ciliated cells induce a leftward fluid flow responsible for the asymmetric expression of Nodal pathway genes in tissues that will originate internal organs. We have recently published that charon/dand5 transcription is an early flow target in zebrafish by being expressed in the LRO, first symmetrically and later asymmetrically to the right where the fluid flow is weaker. We showed that absence of flow originates symmetric charon expression [1]. Pkd2 has been reported as part of a mechanosensor complex that senses flow and induces a calcium inward flux in kidney cells [2] and mouse LRO [3]. In agreement, mouse and zebrafish Pkd2 mutants have LR defects $[4,5]$.

\section{Objective}

Determine if impaired mechanosensing renders the same charon/dand5 phenotype as absent flow.

\section{Methods}

We injected two morpholinos in zebrafish embryos: a dnah7-MO to stop cilia movement [1] and a pkd2-MO. We also co-injected both. We recorded flow by particle analysis, quantified Pkd2 expression and correlated these with charon/dand5 expression patterns by in situ hybridization and qRT-PCR.

\section{Results}

$50-60 \%$ of injected embryos have symmetric charon/dand5 expression when flow is low and homogeneous or when

Pkd2 is absent from LRO ciliary membrane. We will show if charon/dand5 quantification by qRT-PCR is also similar. When both flow and Pkd2 are impaired, $80 \%$ of embryos showed symmetric charon/dand5, which indicates a synergistic effect.

\section{Conclusion}

Although no flow and no Pkd2 have virtually the same phenotype, there seems to be a positive epistasis when both are affected.

\section{Acknowlegements}

Supported by FCT-ANR/BEX-BID/0153/2012 grant and $\mathrm{PD} / \mathrm{BD} / 52420 / 2013 \mathrm{PhD}$ scholarship.

Published: 13 July 2015

\section{References}

1. Sampaio P, Ferreira R, Guerrero A, Pintado P, Tavares B, Amaro J, Smith A, Montenegro-Johnson T, Lopes SS: Left-right organizer flow Dynamics: how much cilia activity reliably yields laterality? Dev Cell 2014, 29(6):716-728.

2. Alenghat FJ, Luo Y, Williams E, Vassilev P, Li X, et al: Polycystins 1 and 2 mediate mechanosensation in the primary cilium of kidney cells. Nat Genet 2003, 33(2):129-137.

3. McGrath J, Somlo S, Makova S, Tian X, Brueckner M: Two populations of node monocilia initiate left-right asymmetry in the mouse. Cell 2003, 114(1):61-73.

4. Pennekamp P, Karcher C, Fisher A, Schweickert A, Skryabin B, Horst J, Blum M, Dworniczak B: The ion channel polycystin-2 is required for leftright axis determination in mice. Current Biol 2002, 12(11):938-943.

5. Schottenfeld J, Sullivan-Brown J, Burdine R: Zebrafish curly up encodes a $\mathrm{Pkd} 2$ ortholog that restricts left-side-specific expression of southpaw. Development 2002, 134(8):1605-1615.

doi:10.1186/2046-2530-4-S1-P39

Cite this article as: Jacinto et al:: Does stopping left-right nodal flow mirror impaired mechanosensation in the left-right organizer? Cilia 2015 4(Suppl 1):P39.
C Biomed Central

(c) 2015 Jacinto et al. This is an Open Access article distributed under the terms of the Creative Commons Attribution License (http:// creativecommons.org/licenses/by/4.0), which permits unrestricted use, distribution, and reproduction in any medium, provided the original work is properly cited. The Creative Commons Public Domain Dedication waiver (http://creativecommons.org/publicdomain/ zero/1.0/) applies to the data made available in this article, unless otherwise stated. 